\title{
Research
}

\section{Protected Areas and Local Communities: an Inevitable Partnership toward Successful Conservation Strategies?}

\author{
Gustavo S. M. Andrade ${ }^{I}$ and Jonathan R. Rhodes ${ }^{1}$
}

\begin{abstract}
Many protected areas (PAs) have followed the conventional and exclusionary approach applied at Yellowstone in 1872. As such, many parks have failed to fully integrate other important factors, such as social, cultural, and political issues. In some cases, this has triggered adverse social impacts on local communities, disrupting their traditional ways of living and limiting their control of and access to natural resources. Such an outcome can undermine protection policies through conflicts between park managers and local communities. The success of conservation strategies through protected areas may lie in the ability of managers to reconcile biodiversity conservation goals with social and economic issues and to promote greater compliance of local communities with PA conservation strategies. However, there are very few quantitative studies identifying what the key factors are that lead to better compliance with PA conservation policies. To address this issue, we conducted a meta-analysis of 55 published case studies from developing countries to determine whether the level of compliance of local communities with PA regulations was related to: (1) PA age, (2) PA area, (3) the existence of a buffer zone, (4) the level of protection as defined by IUCN categories, (5) gross domestic product per capita, (6) population density in the vicinity of PAs, and (7) the level of local community participation in PA management. We found that local community participation in the PA decision-making process was the only variable that was significantly related to the level of compliance with PA polices. In general, the higher the level of participation, the higher the level of compliance. This has important implications for PA management and suggests that greater inclusion of local communities in management should be a key strategy for ensuring the integrity of PAs.
\end{abstract}

Key Words: community-based natural resource management; compliance; conservation; empowerment; participation; protected area management; stewardship

\section{INTRODUCTION}

The establishment of the first protected area (PA) in the world, Yellowstone, in 1872, was a response from the western civilization to uncontrolled degradation of biodiversity and ecosystem services (Lane 2001, Pretty and Smith 2004, Chape et al. 2008). Since then, the number of PAs around the world has increased exponentially. According to Chape et al. (2008), in 2005, the world reached a total of 144,296 protected sites, covering an area of $19,381,000 \mathrm{~km}^{2}$, or $12.9 \%$ of the earth's land area. This is definitely an achievement, but establishment of PAs alone cannot safeguard perpetuation of biodiversity (Wilshusen et al. 2002, Mascia 2003, Aswani and Weiant 2004, Pretty and Smith 2004, Hayes 2006, Ban et al. 2008).

Many PAs have been established following the same conventional and exclusionary top-down approach applied at Yellowstone in 1872 (Lane 2001, Pretty and Smith 2004). As such, many parks have failed to consider other important factors, including social, cultural, and political issues. Frequently, communities are forbidden from extracting natural resources that are important for their livelihoods, and in many instances, traditional communities are removed from their lands with little consultation or adequate compensation (Jim and Xu 2002, Brown 2003, Anthony 2007). Inevitably, this has often triggered adverse social impacts on local communities, disrupting their traditional ways of living (Garcia-Frapolli et al. 2009). This approach can result in hostile attitudes toward conservation strategies (Hamilton et al. 2000, Jim and Xu 2002, Fu et al. 2004, Anthony 2007), jeopardizing protection policies through conflicts between park managers and local communities, reducing the effectiveness of PAs for biodiversity conservation (Lane 2001). For example, in Bwindi Impenetrable Forest, Uganda, after the national park was gazetted, several fires were deliberately set, burning $5 \%$ of the forest (Hamilton et al. 2000). In Tsitsikamma National Park, South Africa, local communities practice illegal activities as a form of retaliation to command-and-control conservation policies (Watts and Faasen 2009).

The importance of incorporating a more participatory approach into PA decision-making processes in order to foster the implementation of conservation strategies has been widely recognized in the literature (Brown 2003, Grainger 2003, Pretty and Smith 2004, Anthony 2007, Reed 2008). Aswani and Weiant (2004) assert that, when local communities are excluded from PA management and their needs and aspirations are ignored, it becomes extremely difficult to enforce conservation policies. However, it is not clear to what extent the involvement of local communities in PA decision-making 
processes in general contributes to enhancing compliance of local communities with PA policies (Wilshusen et al. 2002, Mascia 2003, Pretty and Smith 2003, Aswani and Weiant 2004, Hayes 2006, Ban et al. 2008).

There is some evidence suggesting that local communities are more likely to comply and to commit themselves to long-term conservation strategies when their knowledge and opinions are incorporated into PA decision-making processes (Mascia 2003, Fu et al. 2004, Pretty and Smith 2004, Gelcich et al. 2005). On the other hand, others have suggested that enforcement is the cornerstone for the success of conservation in PAs (Bruner et al. 2001, Lock and Dearden 2005). Therefore, despite extensive knowledge about PA management (Chape et al. 2008), there is still little agreement about how compliance with PA policies could be better achieved. Consequently, a critically important question is, "What are the factors that influence and enhance compliance of communities with PA policies?" Although many case studies have individually assessed this question for specific PAs, few quantitative studies have attempted to make general statements about the factors that lead to better compliance with PA conservation management plans.

We specifically addressed this issue by conducting a metaanalysis of 55 published studies on PAs from developing countries where anthropogenic activities are an important component of the pressures on those reserves. Based on data collected from these studies, we used regression analysis to determine whether the level of compliance was correlated with: local community participation in PA management, age of PA, area of PA, the existence of buffer zones, International Union for Conservation of Nature (IUCN) PA category, gross domestic product (GDP) purchasing power parity (PPP) per capita, or human population density.

\section{METHODS}

We conducted a systematic review and meta-analysis of relevant published studies on PAs and extracted specific information from these studies to allow us to identify which factors may influence the level of community compliance with PA regulations. From the studies identified in the review, we extracted information on the level of compliance (the dependent variable) and identified a range of factors (the independent variables) we considered likely to determine compliance levels. We then statistically tested for relationships among compliance and the independent variables using regression. The aim of our meta-analysis was to combine multiple studies to reach consistent and general conclusions (Petitti 2000).

In order to select relevant independent variables, we first defined four major factors considered likely to influence the level of compliance. These were: (1) PA characteristics; (2) social characteristics; (3) availability of resources; and (4) PA management approach. We then chose specific variables to represent each group (Table 1).

Table 1. Variables hypothesized to influence compliance with protected area (PA) policies and categorized into four key types of factors

\begin{tabular}{|c|c|c|}
\hline Factor & Variable & Source \\
\hline PA characteristics & $\begin{array}{l}\text { Age } \\
\text { Area } \\
\text { Existence of buffer zones } \\
\text { IUCN category }\end{array}$ & $\begin{array}{l}\text { WDPA } 2009 \\
\text { published studies } \\
\text { identified in } \\
\text { systematic review }\end{array}$ \\
\hline $\begin{array}{l}\text { Social } \\
\text { characteristics }\end{array}$ & $\begin{array}{l}\text { Population density } \\
\text { Country adult literacy rates }\end{array}$ & $\begin{array}{l}\text { CIESIN and CIAT } \\
2005 \\
\text { International } \\
\text { Monetary Fund } \\
\text { (IMF) } 2011\end{array}$ \\
\hline $\begin{array}{l}\text { Availability of } \\
\text { resources }\end{array}$ & $\begin{array}{l}\text { GDP PPP (purchasing power } \\
\text { parity) per capita } \\
\text { PA budget per country } \\
\text { PA staff number per } \mathrm{km}^{2} \text { per } \\
\text { country }\end{array}$ & $\begin{array}{l}\text { IMF } 2011 \\
\text { James et al. } 1999 \\
\text { James et al. } 1999\end{array}$ \\
\hline $\begin{array}{l}\text { PA management } \\
\text { approach }\end{array}$ & $\begin{array}{l}\text { Level of local community } \\
\text { participation in PA } \\
\text { management }\end{array}$ & $\begin{array}{l}\text { Published studies } \\
\text { identified in } \\
\text { systematic review }\end{array}$ \\
\hline
\end{tabular}

The variables chosen to represent each group were identified based on a priori hypotheses about the likely drivers of compliance. For instance, PA age was selected because there is an assumption that management will improve over time, and therefore, older PAs are likely to be more efficient than those more recently established (Dudley et al. 2007). Likewise, PA budget, staff, and size have also been selected due to their interconnection with the effectiveness of PA management in the long term (James et al. 1999, Dudley et al. 2007). In developing countries, larger PAs areas require a proportionally large amount of investments, and usually, such countries constantly face funding deficits (James et al. 1999, Bruner et al. 2004, Dudley et al. 2007). In addition, according to James et al. (1999), PA managers are likely to invest more on staffing with their available budget. Moreover, population density was selected because population pressure on natural resources might cause extensive ecological degradation (Mayaka 2002). Therefore, population density could be a crucial predictor influencing local communities' compliance with PA policies. GDP PPP per capita and adult literacy rates were included because we believe that richer countries tend to have a more educated population, facilitating active community engagement in decision-making processes, which might influence compliance with PA policies (Reed 2008, 
Sultana and Abeyasekera 2008). IUCN category was selected because it represents the intended level of protection according to the management objectives of each PA. The category is recognized by international bodies such as the United Nations and many national governments (IUCN 2011). This variable could, therefore, be vital when measuring the level of compliance with PA policies. We included buffer zones in our analysis because they are often used as an outreach tool to minimize impacts of PA implementation on locals (Wells and Brandon 1993, Lynagh and Urich 2002). Therefore, how locals accept this resource area could be an important predictor influencing the level of local communities' compliance with PA policies. Finally, the level of local community participation in PA management seems to be a crucial factor for the longterm success of conservation strategies on PAs, influencing the level of local community compliance with PA policies. Note that analysis of the global drivers of pressure on natural resources is beyond the scope of this study. Therefore, we only consider local factors.

To select studies for inclusion in the meta-analysis and to minimize bias, we used the approach of Pullin and Stewart (2006). We searched the ISI Web of Science and Science Direct databases and published books to identify relevant studies. Initially, we used the key words: "protected areas," "local communities," "participation," "conflicts," "comanagement," "participatory approach," "conservation," "attitude," "perception," “case study," "livelihood," and "community-based natural resource management" in different combinations to search for articles. After reading abstracts, we initially deemed 80 articles to be relevant.

Pullin and Stewart (2006) recommend that, in order to select relevant articles from a large number, it is vital to apply exclusion and inclusion filters, or criteria. We applied two filters as follows:

First, from those 80 articles found in the first search, we read the study area description to make sure that it contained sufficient information to characterize the PA in terms of PA age, area, IUCN category (IUCN 2011), and whether a buffer zone exists, or that this information was available through ancillary sources such as the World Database on Protected Areas (WDPA 2009). Case studies for which we could not find the majority of this information were rejected. The number of relevant articles dropped from 80 to 50 after applying this filter.

Second, we read, in depth, all 50 remaining articles to certify that they were relevant to our question. We rejected articles that did not explain specifically the level of compliance of local communities and the community's level of participation in PA management. After applying this filter, the number of studies dropped from 50 to 35 .
We then conducted a manual search for case studies in published books and the reference lists in the selected articles. After this process, we applied the above two filters to the selected articles again, resulting in a further 20 articles. Therefore, in total, we incorporated 55 relevant case studies in the meta-analysis.

Next, we developed qualitative criteria for categorizing the level of community compliance with PA policies into "high," "moderate," and "low" categories (Table 2) and for categorizing local community participation in PA management into "included," "partially included," and "excluded" categories (Table 3). For each study, we identified whether a buffer zone had been adopted or not. We also determined whether the park was classified as an IUCN category I-IV (stricter protection) or IUCN category V-VI (multi-use) to represent the level of protection of each PA (IUCN 2011; http://www.iucn.org/about/work/programmes/ pa/pa_products/wcpa_categories/).

Table 2. Definitions for level of compliance of local communities with protected area (PA) policies

\begin{tabular}{ll}
\hline \hline Subcategory & Explanation \\
\hline High & $\begin{array}{l}\text { Locals accept park policies and illegal activities rarely } \\
\text { occur-and/or-Locals are satisfied with PA } \\
\text { management. }\end{array}$
\end{tabular}

Moderate Most locals respect the PA policies, but still there are illegal activities, especially the collection of some particular forest products - and/or-Local community is not completely satisfied with PA management.

Low Policies are not respected by local communities and illegal activities are common-and/or-Locals are dissatisfied with PA management.

Table 3. Definitions for level of local community participation in protected area (PA) management

\begin{tabular}{ll}
\hline \hline Subcategory & Explanation \\
\hline Included & $\begin{array}{l}\text { Local communities have effective participation in PA } \\
\text { management and decision making, managing the } \\
\text { reserve's future together with other stakeholders. }\end{array}$ \\
$\begin{array}{ll}\text { Partially } \\
\text { Included }\end{array}$ & $\begin{array}{l}\text { PA managers listen to locals' complaints, and there is also } \\
\text { an attempt to develop alternative economic incentives } \\
\text { within the community. However, this lacks community } \\
\text { participation. }\end{array}$ \\
Excluded & $\begin{array}{l}\text { Neither the problems of local communities, nor their } \\
\text { needs, are being addressed or assessed by PA managers. }\end{array}$ \\
\hline
\end{tabular}


In order to estimate human population density in the vicinity of each park, we overlayed the map of population densityavailable at http://sedac.ciesin.columbia.edu/gpw (Center for International Earth Science Information Network (CIESIN) and Centro Internacional de Agricultura Tropical (CIAT) 2005) — with the map of world PAs - available at http://www. wdpa.org (WDPA 2009). We then applied a 10-km buffer zone around each PA, allowing us to calculate population density for each PA within $10 \mathrm{~km}$ from the PA's border.

To further identify potential problems with collinearity among independent variables we calculated the Pearson correlation coefficient among all pairs of variables. According to Booth et al. (1994), correlations $>0.50$ are considered high, and one of the variables should be excluded because they act as proxies for each other. We followed this protocol here.

Cumulative logit models (Agresti 2002) were then used to model the relationship between the ordinal categorical compliance variable and the explanatory variables. Cumulative logit models are regression models for modeling the relationship between an ordinal response and either continuous and/or categorical explanatory variables (Agresti 2002). The general form of the cumulative logit model used is:

$$
\text { logit }(\operatorname{Pr}[Y \leq j])=\alpha_{j}-\boldsymbol{\beta}^{\prime} \mathbf{X}_{;} j=1_{i} \ldots, J-1
$$

where

$$
\operatorname{Pr}[Y \leq j]
$$

is the probability that the observed compliance category is less than category $j$ for all ordered categories $j=1, \ldots, J-1 ; \alpha_{j}$ is the intercept for category $j ; \beta$ is a vector of regression coefficients; and $\mathbf{X}$ is a vector of explanatory variables. The regression coefficients represent the relationship between the independent variables and the probability of being in a category ranked lower than $j$. Prior to analysis, all noncategorical variables were standardized to have a mean $=0$ and standard deviation $=1$. We then used stepwise procedures (both forward and backward), based on likelihood ratio tests (Hilborn and Mangel 1997) and $p=0.05$ to identify any significant independent variables. We also fitted the saturated model (i.e., the model containing all variables) to the data. Statistical analyses were conducted in R version 2.12.1 (http:// www.r-project.org/) using the "polr" function in the "MASS" package. Initially, due to lack of information for some case studies for PA area and IUCN category, we ran our model selection procedure based on data from 48 studies that had no missing data.

\section{RESULTS}

Among the studies included in our analysis, six were based in South and Central America, 25 in Africa and 24 in Asia (Appendix 1). The studies were based on parks with IUCN categories ranging from strict protection (I-IV) to multi-use $(\mathrm{V}-\mathrm{VI})$. There was substantial variation among the times since the PAs were established, ranging from recently established (less than 10 years old) to reasonably old (more than 50 years old). In addition, the total area protected varied substantially, from very small $\left(<10 \mathrm{~km}^{2}\right)$ to very large $\left(>40,000 \mathrm{~km}^{2}\right)$.

We found that adult literacy rate was correlated with GDP PPP $(r=0.5329)$ and so it was excluded from further analysis. For many countries, up-to-date information on PA budgets and staff numbers was unavailable. However, we found that GDP PPP was somewhat correlated with PA budgets $(r=0.3529)$ and budgets correlated with staff numbers $(r=0.3520)$, and therefore, we used GDP PPP per capita as a surrogate for both variables in the absence of sufficient data on PA budgets and staff numbers.

Consequently, we retained a total of seven independent variables in the analysis: PA age, PA total area, the existence of a buffer zone, the level of intended protection determined by the IUCN category, population density in the vicinity of the PA, country's GDP PPP, and the level of local community participation in PA management.

Both forward and backward stepwise procedures identified local community participation as the only significant predictor variable in the final model. Therefore, as the final model did not include PA area and IUCN category, we were able to run our model for the second time with the full data set from 55 case studies and extracted the regression coefficients. The regression coefficients indicated a positive relationship between community participation and compliance (Table 4). This suggests that enhancing community participation may be one of the most effective ways of achieving compliance with PA policies. However, with a large standard error, there was considerable uncertainty about the value of the coefficient for participation in the "included" category due to a small number of case studies in that category. For the saturated model, although non-significant, age, existence of a buffer zone, and GDP PPP were positively related to compliance and PA area, and IUCN category and population density were negatively related to compliance (Table 5).

Table 4. Regression coefficients for the model with participation as the only independent variable

\begin{tabular}{lll}
\hline \hline $\begin{array}{l}\text { Level of Local } \\
\text { Community }\end{array}$ & Coefficient & Standard Error \\
Participation & & \\
\hline Partially Included & 3.108 & 0.779 \\
Included & 20.271 & 395.781 \\
\hline
\end{tabular}


Table 5. Non-significant coefficients for the saturated model

\begin{tabular}{lll}
\hline \hline Explanatory Variable & Coefficient & Standard Error \\
\hline Participation (partially included) & 3.2667 & 0.8889 \\
Participation (included) & 21.5494 & 406.812 \\
PA age & 0.8413 & 0.483 \\
PA area & -0.3644 & 0.4668 \\
Existence of buffer zone & 1.021 & 0.9352 \\
IUCN category & -0.6628 & 1.1888 \\
Country GDP PPP per capita & 0.1778 & 0.5139 \\
Population density in vicinity of PA & -0.1412 & 0.4506 \\
\hline
\end{tabular}

\section{DISCUSSION}

This meta-analysis has demonstrated that the inclusion of local communities in PA management is likely to be a key determinant of the level of compliance with PA conservation strategies. Therefore, it appears that, in general, local communities are willing to comply with PA policies and rules when they are included in the PA decision-making process. Importantly, this is the first study to explicitly test for the generality of this relationship by formally integrating data across studies. The inclusion of local communities in PA decision-making processes may promote a sense of ownership, where locals cooperatively protect reserves from outsiders and also regulate their own use of natural resources (Horowitz 1998, Aswani et al. 2004, Pretty and Smith 2004, Ban et al. 2009). In Roviana, Solomon Islands, for instance, women involved in a conservation project realized the greater value of being empowered by their own community. As a consequence, they are now managing and monitoring natural resources more comprehensively and setting their own rules to halt illegal activities inside strict resource use zones (Aswani et al. 2004). According to Aswani et al. (2004), the program's success may be attributed to five important factors: (1) a high level of participatory involvement and community leadership, (2) the enhancement of local perception that natural resources have been recovering gradually, (3) a combination of scientific and traditional knowledge, (4) economic incentives created by the alternative income generation, and (5) well-defined boundaries allowing enforcement to take place.

The central pillar of a participatory approach is the creation of a cooperative relationship with all stakeholders, building relationships based on voluntary compliance rather than draconian enforcement (Lane 2001, Mascia 2003). This does not mean that enforcement must not exist, however, it has to be promoted through participatory decision making with all stakeholders involved (Aswani et al. 2004). Rules must be clear and easy to understand, where internal and external boundaries are well defined and recognized by both resource users and PA personnel (Mascia 2003). Although well trained, equipped, and motivated personnel are vital for the success of most PAs, adequate governance must guarantee that penalties will be applied and consistently enforced (Dudley et al. 2007, Nkhata and Breen 2010). Such statements confirm our research findings that promoting local community participation in a PA's decision-making process can be a powerful strategy to enhance compliance with the PA's polices.

Stewardship may only be effective if alternative economic incentive programs are also developed with a participatory process (DeFries 2007). The most important goal in this case is to foster economic development of local communities, improving their livelihoods and at the same time reducing the exploitation of natural resources inside the reserves (DeFries et al. 2007). For example, in Kilum-Ijim Forest, Cameroon, since an income livelihood project began in 1987 through a participatory approach, the park's boundaries have been respected, and the local community now has a positive attitude toward the conservation program (Abbot et al. 2001). Therefore, based on our research results, we could suggest that, without participation and consent of local communities, an outreach program might not be effective in halting illegal activity inside PAs. Moreover, if implemented as the sole strategy, alternative income generation programs could promote dependencies, creating a misconception that locals support external economic assistance (Pretty and Smith 2004). Instead, alternative income generation must be aligned with capacity building, which is likely to play an important role in ensuring long-term sustainability. According to Pretty and Smith (2004), the learning process of ecological and physical aspects of an ecosystem is paramount for the success of any participatory management approach. This promotes positive changes in attitudes toward conservation strategies (Pretty and Smith 2004, Ban et al. 2009). Environmental education and training in technical aspects such as financial management, agriculture improvements, and marketing are some examples of capacity building in local communities (Abbot et al. 2001, Fu et al. 2004, Kaltenborn et al. 2008). Capacity building must also be extended to PA personnel, thus improving their natural resource management, conservation planning, and social skills in conflict resolution and diplomacy (Akama et al. 1995, Fiallo and Jacobson 1995, Ban et al. 2009).

The exploitation of certain natural resources inside PAs on a sustainable basis often improves the living conditions of local populations and, at the same time, can diminish conflicts between locals and PA authorities (De Boer and Baquete 1998, Anthony 2007). We would expect that those PAs under strict protection (IUCN categories I-IV) would permit lower levels of exploitation than those under multi-use arrangements (IUCN categories V-VI), influencing compliance with PA policies. However, the analysis of the non-significant relationship between IUCN category and compliance with PA policies did indeed indicate a possible negative relationship, suggesting that IUCN category might not influence compliance at all. Therefore, we could speculate that the non- 
significant relationship could be attributed to the lack of a relationship between IUCN category and the level of exploitation permitted. As a conservation strategy to reduce conflict between local communities and PA authorities, many PAs under strict protection (IUCN categories I-IV) now allow local communities to extract certain amounts of some forest products at certain times of the year (Dudley et al. 2007). For example, in Batang Ai National Park, Malaysia (IUCN category II), permission was granted for indigenous groups to harvest natural resources inside the park under certain conditions (Horowitz 1998). This is evidence of paradigm shift, where PA managers are noticing the advantages of working with locals and understanding their needs without jeopardizing the ecological integrity of PAs. Our finding suggests that compliance is driven primarily by local involvement in the PA decision-making process and not the intended protection level. In this case, we could speculate that the intended protection level will have little bearing on compliance once park authorities better understand the peculiarities of a PA and its surrounding communities, giving flexibility to predetermined rules, and aligning local communities' needs and aspirations with the local biodiversity conservation strategy.

Buffer zones are usually areas around PAs that often have dual roles: conservation, provision of additional protection of core conservation zones from disturbances, and development, benefiting local communities economically (Wells and Brandon 1993, Lynagh and Urich 2002). We identified a positive relationship between compliance and the existence of a buffer zone, suggesting that buffer zones may somewhat enhance compliance, but this was also a non-significant relationship. The success of buffer zones may be influenced by many factors that we have not taken into consideration in this study, such as availability of natural resources, political decisions, corruption, or social equality. However, the limited impact of buffer zones on compliance may be more related to their implementation, rather than the concept per se (Wilshusen et al. 2002). Lack of local community empowerment in decision making, transparency and an adequate benefit-sharing system are major drawbacks of buffer zone programs (Budhathoki 2004). For instance, in Royal Chitwan National Park, Nepal, park revenue is used to compensate for restrictions on natural resource use rather than to sponsor outreach programs and collaborative management with local communities (Budhathoki 2004). However, in Lobeke National Park, Cameroon, community hunting areas (the buffer zone) were gazetted in an exemplary participatory approach, allowing local residents to generate substantial financial resources from sport hunting, which are used to sponsor several community development activities, such as community farms, purchasing basic medical supplies, and running education programs (Usongo and Nkanje 2004). It is clear that any PA decision-making process could potentially affect the livelihoods of those living adjacent to PAs. Therefore, based on our findings, it is reasonable to suggest that there is limited scope to improve compliance with PA conservation strategies if local communities are not engaged in crucial PA decision making, such as the implementation and management of buffer zones.

Our analysis showed that PA age and area were not significantly related to the level of compliance. Despite nonsignificance, it is realistic to suggest that more time and effort may improve management and, indeed, there was a positive relationship between PA age and compliance. However, time alone (i.e., PA age) will not necessarily result in improvement unless an effective management plan is put in place (Dudley et al. 2007). This may be one of the reasons why we did not find that PA age was a significant factor relating to local community compliance. Area of a PA showed a negative, although again non-significant, relationship with compliance, possibly suggesting that the bigger the PA area the lower the compliance. For developing countries, due to limited financial resources, equipment, and staff, patrolling and enforcing policies for large PAs may often be difficult, which could explain this weak relationship (Horowitz 1998, Hamilton et al. 2000, Gelcich et al. 2005, Ban et al. 2008, 2009). However, we could speculate that patrolling and management costs of such big areas can be reduced with local community collaboration, wherein locals could voluntarily act as local law enforcers, inhibiting and reducing outsiders' illegal activity in PAs (Horowitz 1998, Aswani et al. 2004, Pretty and Smith 2004, Ban et al. 2009). Such stewardship can only take place if local communities feel included in the decision-making process, securing their livelihoods and natural resources that they rely upon.

We may also be able to draw some insights from our analysis into how population density and country-level GDP PPP per capita relate to compliance, despite the non-significance of these explanatory variables. For example, GDP PPP per capita was positively related to compliance, suggesting a tendency for richer countries to have higher compliance with PA policies. However, other factors such political will, corruption, and social inequality might ultimately determine the effectiveness of financial resources, thus influencing our results. There may also have been scale mismatches between the country-level GDP data and the economic status of populations living in the vicinity of PAs. Population density tended to be negatively related to compliance, suggesting that higher population densities around PAs may result in lower compliance with PA policies. However, once again, there may have been scale mismatches between the scale at which human population density was measured and the scale at which local communities interact with PAs, thus affecting our results.

Although we have demonstrated that the inclusion of local communities in PA decision making tends to improve 
compliance with PA policies, further studies are needed to understand the impact of these strategies on biodiversity outcomes; this was beyond the scope of this study. However, many PAs are undertaking assessments of management effectiveness to evaluate how well they are meeting their conservation goals (Hockings et al. 2006). It was expected that, from this process, at least $30 \%$ of PAs in each country would have completed these assessments by 2010 (Hockings et al. 2006). With this information, future studies may be able to determine key strategies that meet conservation goals, while also promoting social and economic benefits to local populations living adjacent to PAs. Moreover, there are other variables, such as cultural attitudes, tradition, stewardship, and type of governance that might influence the level of local community compliance with PA policies. However, such information can only be acquired when the peculiarities of each PA are studied in depth. So far, this information is not available. We believe that future studies on PA management could contribute to a more thorough evaluation of those variables, assisting PA managers to resolve issues with PA decision-making processes.

\section{CONCLUSION AND IMPLICATIONS FOR PROTECTED AREA MANAGEMENT}

Removing local communities from lands that they have been exploiting for generations without consultation or adequate compensation can result in retaliation and hostile attitudes toward PA objectives. Restricting local access to natural resources, which can play a crucial role in their livelihoods, health, and culture, might favor biodiversity conservation in the short term. However, in the long term, such strategies may fail to preserve biodiversity if park authorities disregard the importance of simultaneously promoting active local community participation in PA management, capacity building, implementing adequate outreach programs and also efficient governance, guaranteeing that penalties will be applied and consistently enforced. The recognition of the dependence of adjacent communities on some natural resources inside PAs has revealed to decision makers the real downside of the conventional command-and-control management systems (Fu et al. 2004). Thus, the importance of collaborative management to enhance biodiversity protection has become critical for the long-term success of PAs (Mbile et al. 2005, Yonariza and Webb 2007, Kaltenborn et al. 2008).

Establishing and maintaining PAs require both political and financial commitment in the long term. Often PAs in developing countries have a common funding deficit feature (Bruner et al. 2004). Considering this, we believe that partnerships with local communities and PA authorities could promote a win-win outcome. Allowing more active local participation in PA decision-making processes means that PA financial resources can be better invested in improving governance, local capacity building, participation, and outreach programs rather than draconian measures. For instance, patrolling and management costs could be reduced with local collaboration (Boissière et al. 2009).

We have shown that one of the most important general strategies for developing local community acceptance of PAs may be community participation in PA management. Including locals in decision-making processes can potentially create a sense of stewardship, where local residents collaborate with PA managers and act together to conserve biodiversity in PAs and local livelihoods (Horowitz 1998). However, putting such concepts into practice is not an easy task. There are no simple formulae for combining conservation objectives with local community needs. What has worked in one PA may not have worked in another. Understanding the peculiarities of each PA and the people who live in and around them is paramount for the success of each PA's conservation program. How we effectively manage today's PAs will determine whether those areas will remain under protection, or whether we will continue to see their gradual degradation.

Responses to this article can be read online at: http://www.ecologyandsociety.org/issues/responses. php/5216

\section{Acknowledgments:}

We would like to thank especially Zuleica Buces Lopez and Beth Sheree for proofreading and editing services and also the two anonymous reviewers whose comments on previous versions of this manuscript improved it substantially. A special thanks to CIESIN and CIAT for providing a complete population density map and also to WDPA for making available thorough information about protected areas. This research was conducted with the support of funding from the Australian Research Council Centre of Excellence for Environmental Decisions.

\section{LITERATURE CITED}

Abbot, J., D. Thomas, A. Gardner, S. Neba, and M. Khen. 2001. Understanding the links between conservation and development in the Bamenda Highlands, Cameroon. World Development 29:1115-1136.

Agresti, A. 2002. Building and applying logistic regression models. Pages 211-266 in A. Agresti, editor. Categorical data analysis Second edition. Wiley, Hoboken, New Jersey, USA.

Akama, J., C. Lant, and G. Burnett. 1995. Conflicting attitudes towards state wildlife conservation programs in Kenya. Society and Natural Resources 8:133-144. http://dx.doi. org/10.1080/08941929509380907 
Anthony, B. 2007. The dual nature of parks: attitudes of neighbouring communities towards Kruger National Park, South Africa. Environmental Conservation 34:236-245. http://dx.doi.org/10.1017/S0376892907004018

Aswani, S., and P. Weiant. 2004. Scientific evaluation in women's participatory management: monitoring marine invertebrate refugia in the Solomon Islands. Human Organization 63(3):301-319.

Ban, N., G. Hansen, M. Jones, and A. Vincent. 2009. Systematic marine conservation planning in data-poor regions: socioeconomic data is essential. Marine Policy 33:794-800. http://dx.doi.org/10.1016/j.marpol.2009.02.011

Ban, N., C. Picard, and A. Vincent. 2008. Moving toward spatial solutions in marine conservation with indigenous communities. Ecology and Society 13(1): 32. [online] URL: http://www.ecologyandsociety.org/vol13/iss1/art32/

Boissière, M., D. Sheil, I. Basuki, M. Wan, and H. Le. 2009. Can engaging local people's interests reduce forest degradation in central Vietnam? Biodiversity Conservation 18:2743-2757. http://dx.doi.org/10.1007/s10531-009-9627-1

Booth, G. D., M. Niccolucci, and E. Schuster. 1994. Identifying proxy sets in multiple linear regression: an aid to better coefficient interpretation. U.S. Department of Agriculture, Forest Service, Intermountain Research Station, Ogden, Utah, USA.

Brown, K. 2003. Integrating conservation and development: a case of institutional misfit. Frontiers in Ecology and the Environment 1(9):749-487. http://dx.doi.org/10.1890/1540-9295 (2003)001[0479:ICADAC]2.0.CO;2

Bruner, A., R. Gullison, and A. Balmford. 2004. Financial cost and shortfalls managing and expanding protected-area systems in developing countries. BioScience 54(12):11191126. http://dx.doi.org/10.1641/0006-3568(2004)054[1119: FCASOM $\rceil 2.0 . \mathrm{CO} ; 2$

Bruner, A., R. E. Gullison, R. E. Rice, and G. A. B. da Fonseca. 2001. Effectiveness of park in protecting tropical biodiversity. Science 291:125-127. http://dx.doi.org/10.1126/science.291.5501.125

Budhathoki, P. 2004. Linking communities with conservation in developing countries: buffer zone management initiatives in Nepal. Oryx 38:334-341. http://dx.doi.org/10.1017/ $\underline{\mathrm{S} 0030605304000584}$

Center for International Earth Science Information Network (CIESIN), Columbia University; and Centro Internacional de Agricultura Tropical (CIAT). 2005. Gridded population of the world, version 3 (GPWv3): population density grid. Socioeconomic Data and Applications Center (SEDAC), Columbia University, Palisades, New York, USA. [online] URL: http://sedac.ciesin.columbia.edu/gpw
Chape, S., M. Spalding, M. Taylor, A. Putney, N. Ishwaran, J. Thorsell, D. Blasco, J. Robertson, P. Bridgewater, J. Harrison, and E. McManus. 2008. History, definitions, value and global perspective. Pages 1-35 in S. Chape, M. Spalding, and M. Jenkins, editors. The world's protected areas-status, values and prospect in the 21 st century. University of California Press, Los Angeles, California, USA.

de Boer, W., and D. S. Baquete. 1998. Natural resource use, crop damage and attitude of rural people in the vicinity of the Maputo Elephant Reserve, Mozambique. Environmental Conservation 25:208-218. http://dx.doi.org/10.1017/ $\underline{\text { S0376892998000265 }}$

DeFries, R., A. Hansen, B. Turner, R. Reid, and J. Liu. 2007. Land use change around protected areas: management to balance human needs and ecological function. Ecological Application 17(4):1031-1038. http://dx.doi.org/10.1890/05-1111

Dudley, N., A. Belokurov, L. Higgins-Zogip, M. Hockings, S. Stolton, and N. Burgess. 2007. Tracking progress in managing protected areas around the world. World Wildlife Fund International, Gland, Switzerland.

Fiallo, E., and S. Jacobson. 1995. Local communities and protected areas: attitude of rural residents towards conservation and Machalilla National Park, Ecuador. Environmental Conservation 22:241-249. http://dx.doi. org/10.1017/S037689290001064X

Fu, B., K. Wang, Y. Lu, S. Liu, K. Ma, L. Chen, and G. Liu. 2004. Entangling the complexity of protected area management: the case of Wolong Biosphere Reserve, southwestern China. Environmental Management 33:788798. http://dx.doi.org/10.1007/s00267-004-0043-8

Garcia-Frapolli, E., G. Ramos-Fernandes, E. Galicia, and A. Serrano. 2009. The complex reality of biodiversity conservation through natural protected area policy: three cases studies from Yucatan Peninsula, Mexico. Land Use Policy 26:715-722. http://dx.doi.org/10.1016/j.landusepol.2008.09.008

Gelcich, S., G. Edward-Jones, and M. Kaiser. 2005. Importance of attitudinal differences among artisanal fishers toward co-management and conservation of marine resources. Conservation Biology 19(3): 865-875. http://dx.doi. org/10.1111/j.1523-1739.2005.00534.x

Grainger, J. 2003. People are living in the park. Linking biodiversity conservation to community development in the Middle East region: a case study from the Saint Katherine Protectorate, Southern Sinai. Journal of Arid Environment 54:29-38. http://dx.doi.org/10.1006/jare.2001.0894

Hamilton, A., A. Cunningham, D. Byarugaba, and F. Kayanja. 2000. Conservation in a region of political instability: Bwindi Impenetrable Forest, Uganda. Conservation Biology 14 (6):1722-1725. 
Hayes T. M. 2006. Parks, people, and forest protection: an institutional assessment of the effectiveness of protected areas. World Development 34(12):2026-2075. http://dx.doi.org/10.1016/ j.worlddev.2006.03.002

Hilborn, R., and M. Mangel. 1997. The ecological detective. Confronting models with data. Princeton University Press, Princeton, New Jersey, USA.

Hockings, M., S. Stolton, F. Leverington, N. Dudley, J. Courrau, and P. Valentine. 2006. Evaluating effectiveness: a framework for assessing management effectiveness of protected areas. IUCN, Cambridge, UK. http://dx.doi. org/10.2305/IUCN.CH.2006.PAG.14.en

Horowitz, L. S. 1998. Integrating indigenous resource management with wildlife conservation: a case study of Batang Ai National Park, Sarawak, Malaysia. Human Ecology 26:371-403. http://dx.doi.org/10.1023/A:1018752115074

International Monetary Fund (IMF). 2011. World economic outlook database, April 2011. [online] URL:http://www.imf. org/external/pubs/ft/weo/2011/01/weodata/weoselco.aspx? $\mathrm{g}=2001 \& \mathrm{sg}=$ All + countries

International Union for the Conservation of Nature (IUCN). 2011. IUCN protected area management categories. [online] URL: http://www.iucn.org/about/work/programmes/pa/pa products/ wcpa categories/

James, N., M. Green, and J. Paine. 1999. A global review of protected area budgets and staff. WCMC-World Conservation Press, Cambridge, UK.

Jim, C., and S. Xu. 2002. Stifled stakeholders and subdue participation: interpreting local responses toward Shimentai Nature Reserve in South China. Environmental Management 30:327-341. http://dx.doi.org/10.1007/s00267-002-2623-9

Kaltenborn, B., J. Nyahongo, J. Kidegesho, and H. Haaland. 2008. Serengeti National Park and its neighbours-do they interact? Journal for Nature Conservation 16:96-108. http:// dx.doi.org/10.1016/j.jnc.2008.02.001

Lane, M. B. 2001. Affirming new directions in planning theory: comanagement of protected areas. Society and Natural Resources 14:657-671.

Locke, H., and P. Dearden. 2005. Rethinking protected area categories and the new paradigm. Environmental Conservation 32(1):1-10. http://dx.doi.org/10.1017/ $\underline{\mathrm{S} 0376892905001852}$

Lynagh, F., and P. Urich. 2002. A critical review of buffer zone theory and practice: a Philippine case study. Society and Natural Resources 15:129-145. http://dx.doi.org/10.1080/089419202753403319

Mascia, M. B. 2003. The human dimension of coral reef marine protected areas: recent social science research and its policy implication. Conservation Biology 17(2): 630-632. http://dx.doi.org/10.1046/j.1523-1739.2003.01454.x

Mayaka, T. 2002. Wildlife co-management in the Benoue National Park-Complex, Cameroon: a bumpy road to institutional development. World Development, 30:2001-2016. http://dx.doi.org/10.1016/S0305-750X(02)00111-0

Mbile, P., V. Vabi, M. Meboka, D. Okon, J. Arrey-Mbo, F. Nkongho, and E. Ebong. 2005. Linking management and livelihood in environmental conservation: case of Korup National Park Cameroon. Journal of Environmental Management 76:1-13. http://dx.doi.org/10.1016/j. jenvman.2005.01.009

Nkhata, B. A., and C. Breen. 2010. A framework for exploring integrated learning systems for the governance and management of public protected areas. Environmental Management 45:403-413. http://dx.doi.org/10.1007/ s00267-009-9410-9

Petitti, D. 2000. Overview of the methods. Pages 13-32 in D. Petitti, editor. Meta-analysis, decision analysis and costeffectiveness analysis: methods for quantitative synthesis in medicine. Oxford University Press, Oxford, UK. http://dx.doi. org/10.1093/acprof:oso/9780195133646.003.02

Pretty, J., and D. Smith. 2004. Social capital in biodiversity conservation and management. Conservation Biology 18 (3):631-638. http://dx.doi.org/10.1111/j.1523-1739.2004.00126. $\underline{x}$

Pullin, A., and G. Stewart. 2006. Guidelines for systematic review in conservation and environmental management. Conservation Biology 20:1647-1656. http://dx.doi.org/10.1111/ j.1523-1739.2006.00485.x

Reed, M. S. 2008 Stakeholder participation for environmental management: a literature review. Biological Conservation 141:2417-2431. http://dx.doi.org/10.1016/j.biocon.2008.07.014

Sultana, P., and S. Abeyasekera. 2008. Effectiveness of participatory planning for community management of fisheries in Bangladesh. Journal of Environmental Management 86:201-213. http://dx.doi.org/10.1016/j.

jenvman.2006.12.027

Usongo, L., and T. Nkanje. 2004. Participatory approaches towards forest conservation: the case of Lobeke National Park, southeast Camerron. International Journal of Sustainable Development and World Ecology 11:119-127. http://dx.doi. org/10.1080/13504500409469816

Watts, S., and H. Faasen. 2009. Community-based conflict resolution strategies for sustainable management of the Tsitsikamma National Park, South Africa. South African Geographical Journal 91:25-37. http://dx.doi.

org/10.1080/03736245.2009.9725327 
Wells, M., and K. E. Brandon. 1993. The principle and practice of buffer zones and local participation in biodiversity conservation. AMBIO, 22:157-161.

Wilshusen, P. R., S. R. Brechin, C. L. Fortwangler, and P. C. West. 2002. Reinventing a square wheel: critique of a resurgent "protection paradigm" in international biodiversity conservation. Society and Natural Resources 15:17-40. http:// dx.doi.org/10.1080/089419202317174002

World Database on Protected Areas (WDPA). 2009. [online] URL : http://www.wdpa.org/

Yonariza, and E. L. Webb. 2007. Rural household participation in illegal timber felling in a protected area of West Sumatra, Indonesia. Environmental Conservation 34 (1):73-82. http://dx.doi.org/10.1017/S0376892907003542 


\begin{tabular}{|c|c|c|c|c|c|c|c|c|c|c|c|c|}
\hline \multirow{2}{*}{ P.A NAME } & \multirow{2}{*}{\begin{tabular}{|c|} 
OUTCOMES \\
\\
Level of compliance of \\
local community with \\
park's policies
\end{tabular}} & \multicolumn{8}{|c|}{ CHARACTERISTICS } & \multirow[b]{2}{*}{$\begin{array}{l}\text { Notes: Level of } \\
\text { Compliance** }\end{array}$} & \multirow[b]{2}{*}{$\begin{array}{l}\text { Notes: Level of } \\
\text { Participation**** }\end{array}$} & \multirow[b]{2}{*}{$\begin{array}{l}\text { INFORMATION } \\
\text { SOURCE }\end{array}$} \\
\hline & & Country & $\begin{array}{c}\text { Protected Area } \\
\text { Age }\end{array}$ & $\operatorname{Area}\left(\mathrm{km}^{2}\right)$ & $\begin{array}{l}\text { Existence of } \\
\text { Buffer Zones }\end{array}$ & $\begin{array}{l}\text { IUCN P.A } \\
\text { Category }\end{array}$ & $\begin{array}{l}2009 \text { GDP PPP per } \\
\text { capta (Intl } \\
\text { dollars) }\end{array}$ & $\begin{array}{l}\text { Population Density } \\
\text { in Vicinity of PA }\end{array}$ & \begin{tabular}{|c|} 
Local community \\
participation-decision \\
making
\end{tabular} & & & \\
\hline $\begin{array}{l}\text { Lencois Maranheses National } \\
\text { Park }\end{array}$ & Low & Brazil & 30 & 1,550 & no & II & $10,453.25$ & 10.53 & Excluded & $\begin{array}{l}\text { Frequent illegal fishing } \\
\text { detected }\end{array}$ & $\begin{array}{c}\text { No participation:there isn't } \\
\text { any form of consultation or } \\
\text { interaction between } \\
\text { community and PA } \\
\text { managers. }\end{array}$ & (Abakerli, 2001) \\
\hline Kayapo Indigenous Area & High & Brazil & 22 & 32,972 & no & not known & $10,453.25$ & 0.91 & Included & $\begin{array}{l}\text { no illegal activity } \\
\text { detected }\end{array}$ & $\begin{array}{l}\text { Community plays a major } \\
\text { role on PA management }\end{array}$ & $\begin{array}{l}\text { (Zimmerman, Peres, } \\
\text { Malcolm, \& Turner, } \\
\text { 2001) }\end{array}$ \\
\hline $\begin{array}{l}\text { Jigme Singye Wangchuck } \\
\text { National Park }\end{array}$ & Moderate & Bhutan & 16 & 1,730 & yes & II & $5,131.23$ & 69.29 & Partially Included & $\begin{array}{l}\text { Some illegal activity } \\
\text { detected: Cattle grazing, } \\
\text { Fuelwood, NTFP* \& } \\
\text { poaching }\end{array}$ & $\begin{array}{c}\text { Community is consulted } \\
\text { through some meetings, } \\
\text { but does not influence PA } \\
\text { management }\end{array}$ & $\begin{array}{l}\text { (Wang, Lassoie, \& } \\
\text { Curtis, 2006) }\end{array}$ \\
\hline Korup National Park & Low & Cameroon & 50 & 1,294 & no & II & $2,139.57$ & 33.98 & Excluded & $\begin{array}{l}\text { Frequent illegal } \\
\text { Poaching \& NTFP* } \\
\text { detected }\end{array}$ & \begin{tabular}{|c|} 
No participation:there isn't \\
any form of consultation or \\
interaction between \\
community and PA \\
managers.
\end{tabular} & (Mbile, et al., 2005) \\
\hline Lobeke National Park & High & Cameroon & 37 & 1,838 & yes & II & $2,139.57$ & 4.06 & Included & $\begin{array}{l}\text { no illegal activity } \\
\text { detected }\end{array}$ & $\begin{array}{l}\text { Community plays a major } \\
\text { role on PA management }\end{array}$ & $\begin{array}{l}\text { (Usongo \& Nkanje, } \\
\text { 2004) }\end{array}$ \\
\hline Benoue National Park & Moderate & Cameroon & 43 & 1,665 & yes & II & $2,139.57$ & 7.95 & Partially Included & $\begin{array}{l}\text { Some illegal activity } \\
\text { detected: agriculture, } \\
\text { poaching \& fishing }\end{array}$ & $\begin{array}{c}\text { Community is consulted } \\
\text { through some meetings, } \\
\text { but does not influence PA } \\
\text { management }\end{array}$ & (Mayaka, 2002) \\
\hline Waza National Park & Low & Cameroon & 43 & 1,407 & no & II & $2,139.57$ & 58.20 & Partially Included & \begin{tabular}{|l|} 
Frequent illegal activity \\
detected: Cattle grazing, \\
Fishing, \\
poaching,fuelwood,loggi \\
ng \& NTFP*
\end{tabular} & $\begin{array}{c}\text { Community is consulted } \\
\text { through some meetings, } \\
\text { but does not influence PA } \\
\text { management }\end{array}$ & (Bauer, 2003) \\
\hline Kilum-Ijim Forest & High & Cameroon & 24 & 200 & no & not known & $2,139.57$ & 150.84 & Included & $\begin{array}{l}\text { no illegal activity } \\
\text { detected }\end{array}$ & $\begin{array}{c}\text { Community plays a major } \\
\text { role on PA management }\end{array}$ & $\begin{array}{l}\text { (Abbot, Thomas, } \\
\text { Gardner, Neba, \& } \\
\text { Khen, 2001) }\end{array}$ \\
\hline Wolong Nature Reserve & Low & China & 32 & 2,000 & no & VI & $6,785.87$ & 69.03 & Excluded & \begin{tabular}{|l|} 
Frequent illegal activity \\
detected: Agriculture, \\
Cattle Grazingg, \\
fuelwood \& NTFP*
\end{tabular} & $\begin{array}{c}\text { No participation:there isn't } \\
\text { any form of consultation or } \\
\text { interaction between } \\
\text { community and PA } \\
\text { managers. }\end{array}$ & (Fu, et al., 2004) \\
\hline Shimentai Nature Reserve & Low & China & 13 & 822 & yes & $\mathrm{v}$ & $6,785.87$ & 120.90 & Excluded & $\begin{array}{l}\text { Frequent illegal activity } \\
\text { detected: fuelwood, wild } \\
\text { honey, logging, poaching } \\
\& \text { NTFP* }\end{array}$ & $\begin{array}{c}\text { No participation:there isn't } \\
\text { any form of consultation or } \\
\text { interaction between } \\
\text { community and PA } \\
\text { managers. }\end{array}$ & $(\operatorname{Jim} \& \mathrm{Xu}, 2002)$ \\
\hline Xishuangbanna Nature Reserve & Moderate & China & 53 & 1,428 & no & $\mathrm{v}$ & $6,785.87$ & 53.20 & Partially Included & $\begin{array}{l}\text { Some illegal activity } \\
\text { detected:Fuelwood,Poac } \\
\text { hing, timber \&NTFP* }\end{array}$ & \begin{tabular}{|c|}
$\begin{array}{c}\text { Community is consulted } \\
\text { through some meetings, } \\
\text { but does not influence PA } \\
\text { management }\end{array}$ \\
\end{tabular} & $\begin{array}{c}\text { (Albers \& Grinspoon, } \\
\text { 1997) }\end{array}$ \\
\hline
\end{tabular}




\begin{tabular}{|c|c|c|c|c|c|c|c|c|c|c|c|c|}
\hline \multirow[b]{2}{*}{ P.A NAME } & \multirow{2}{*}{\begin{tabular}{|c|} 
OUTCOMES \\
\\
Level of compliance of \\
local community with \\
park's policies
\end{tabular}} & \multicolumn{8}{|c|}{ CHARACTERISTICS } & \multirow[b]{2}{*}{$\begin{array}{l}\text { Notes: Level of } \\
\text { Compliance*** }\end{array}$} & \multirow[b]{2}{*}{$\begin{array}{l}\text { Notes: Level of } \\
\text { Participation***** }\end{array}$} & \multirow[b]{2}{*}{$\begin{array}{l}\text { INFORMATION } \\
\text { SOURCE }\end{array}$} \\
\hline & & Country & $\begin{array}{c}\text { Protected Area } \\
\text { Age }\end{array}$ & $\operatorname{Area}\left(\mathbf{k m}^{2}\right)$ & $\begin{array}{l}\text { Existence of } \\
\text { Buffer Zones }\end{array}$ & $\begin{array}{l}\text { IUCN P.A } \\
\text { Category }\end{array}$ & $\begin{array}{l}2009 \text { GDP PPP per } \\
\text { capta (Intl } \\
\text { dollars) }\end{array}$ & $\begin{array}{c}\text { Population Density } \\
\text { in Vicinity of PA }\end{array}$ & \begin{tabular}{|c} 
Local community \\
participation-decision \\
making
\end{tabular} & & & \\
\hline Machalilla National Park & Low & Ecuador & 32 & 750 & no & II & $7,573.13$ & 38.97 & Excluded & $\begin{array}{l}\text { Frequent illegal activity } \\
\text { detected: Agriculture, } \\
\text { Cattle grazing \& Fishing }\end{array}$ & $\begin{array}{c}\text { No participation:there isn't } \\
\text { any form of consultation or } \\
\text { interaction between } \\
\text { community and PA } \\
\text { managers. }\end{array}$ & $\begin{array}{l}\text { (Fiallo \& Jacobson, } \\
\text { 1995) }\end{array}$ \\
\hline St Katherine Protectorate & High & Egypt & 23 & 4,712 & no & $\mathrm{VI}$ & $6,105.91$ & 4.51 & Included & $\begin{array}{l}\text { no illegal activity } \\
\text { detected }\end{array}$ & $\begin{array}{c}\text { Community plays a major } \\
\text { role on PA management }\end{array}$ & (Grainger, 2003) \\
\hline Nanda Devi Biosphere Reserve & Low & India & 23 & 2,236 & yes & not known & $3,039.48$ & 31.38 & Partially Included & $\begin{array}{l}\text { no illegal activity } \\
\text { mentioned on article but } \\
\text { locals are extremely } \\
\text { dissatisfied with PA's } \\
\text { managemnet. }\end{array}$ & $\begin{array}{c}\text { Passive: community is } \\
\text { consulted but does not } \\
\text { influence PA management }\end{array}$ & $\begin{array}{c}\text { (Maikhuri, S., \& Rao, } \\
\text { 2001) }\end{array}$ \\
\hline Rajaji National Park & Low & India & 28 & 820 & no & II & $3,039.48$ & 615.66 & Excluded & $\begin{array}{l}\text { Frequent illegal activity } \\
\text { detected: Cattle grazing, } \\
\text { fuelwood \& NTFP* }\end{array}$ & $\begin{array}{c}\text { No participation:there isn't } \\
\text { any form of consultation or } \\
\text { interaction between } \\
\text { community and PA } \\
\text { managers. }\end{array}$ & (Ogra, 2009) \\
\hline $\begin{array}{l}\text { Kalakad Mundanthurai Tiger } \\
\text { Reserve }\end{array}$ & Moderate & India & 35 & 900 & yes & IV & $3,039.48$ & 565.29 & Partially Included & $\begin{array}{l}\text { Some illegal activity } \\
\text { detected: Cattle grazing, } \\
\text { fuelwood \& NTFP* }\end{array}$ & \begin{tabular}{|c|}
$\begin{array}{c}\text { Community is consulted } \\
\text { through some meetings, } \\
\text { but does not influence PA } \\
\text { management }\end{array}$ \\
\end{tabular} & \begin{tabular}{|c} 
(Arjunan, Holmes, \\
Puyravaud, \& Davidar, \\
2006) \\
\end{tabular} \\
\hline Gir National Park & Low & India & 31 & 1,265 & no & II & $3,039.48$ & 231.35 & Partially Included & $\begin{array}{l}\text { Frequent illegal activity } \\
\text { detected: Cattle grazing, } \\
\text { fuelwood \& NTFP* }\end{array}$ & \begin{tabular}{|c|} 
Community is consulted \\
through some meetings, \\
but does not influence PA \\
management
\end{tabular} & $\begin{array}{c}\text { (Mukherjee \& Borad, } \\
\text { 2004) }\end{array}$ \\
\hline Sariska tiger Reserve & Moderate & India & 56 & 492 & no & IV & $3,039.48$ & 400.59 & Excluded & \begin{tabular}{|l|} 
Some illegal activity \\
detected: Agriculture, \\
Cattle grazing, Fuelwood \\
\& NTFP*
\end{tabular} & $\begin{array}{c}\text { No participation:there isn't } \\
\text { any form of consultation or } \\
\text { interaction between } \\
\text { community and PA } \\
\text { managers. }\end{array}$ & (Sekhar, 2003) \\
\hline Tadoba Andahari Tiger Reserve & Low & India & 18 & 625 & yes & II & $3,039.48$ & 153.33 & Excluded & $\begin{array}{l}\text { Frequent illegal activity } \\
\text { detected: Cattle grazing, } \\
\text { fuelwood \& NTFP* }\end{array}$ & $\begin{array}{c}\text { No participation:there isn't } \\
\text { any form of consultation or } \\
\text { interaction between } \\
\text { community and PA } \\
\text { managers. }\end{array}$ & $\begin{array}{c}\text { (Nagendra, Pareeth, \& } \\
\text { Ghate, 2006) }\end{array}$ \\
\hline Barisan I Nature Reserve & Low & Indonesia & 91 & 740 & no & VI & $4,155.45$ & 465.43 & Excluded & $\begin{array}{l}\text { Frequent illegal activity } \\
\text { detected: Poaching, } \\
\text { logging \& NTFP* }\end{array}$ & $\begin{array}{c}\text { No participation:there isn't } \\
\text { any form of consultation or } \\
\text { interaction between } \\
\text { community and PA } \\
\text { managers. }\end{array}$ & $\begin{array}{l}\text { (Yonariza \& Webb, } \\
\text { 2007) }\end{array}$ \\
\hline Nairobi National Park & Low & Kenya & 65 & 117 & no & II & $1,614.07$ & $2,495.16$ & Excluded & $\begin{array}{l}\text { Frequent illegal activity } \\
\text { detected: Agriculture, } \\
\text { cattle grazing \& } \\
\text { poaching }\end{array}$ & $\begin{array}{c}\text { No participation:there isn't } \\
\text { any form of consultation or } \\
\text { interaction between } \\
\text { community and PA } \\
\text { managers. }\end{array}$ & $\begin{array}{l}\text { (Akama, Lant, \& } \\
\text { Burnett, 1995) }\end{array}$ \\
\hline $\begin{array}{l}\text { Tsavo National Park ( East \& } \\
\text { West part) }\end{array}$ & Low & Kenya & 63 & 20,812 & no & II & $1,614.07$ & 11.66 & Excluded & $\begin{array}{l}\text { Frequent illegal activity } \\
\text { detected: Agriculture, } \\
\text { cattle grazing \& } \\
\text { poaching }\end{array}$ & $\begin{array}{c}\text { No participation:there isn't } \\
\text { any form of consultation or } \\
\text { interaction between } \\
\text { community and PA } \\
\text { managers. }\end{array}$ & $\begin{array}{l}\text { (Akama, Lant, \& } \\
\text { Burnett, 1995) }\end{array}$ \\
\hline
\end{tabular}




\begin{tabular}{|c|c|c|c|c|c|c|c|c|c|c|c|c|}
\hline \multirow[b]{2}{*}{ P.A NAME } & \multirow{2}{*}{\begin{tabular}{|c|} 
OUTCOMES \\
\\
Level of compliance of \\
local community with \\
park's policies
\end{tabular}} & \multicolumn{8}{|c|}{ CHARACTERISTICS } & \multirow[b]{2}{*}{$\begin{array}{l}\text { Notes: Level of } \\
\text { Compliance** }\end{array}$} & \multirow[b]{2}{*}{$\begin{array}{l}\text { Notes: Level of } \\
\text { Participation**** }\end{array}$} & \multirow[b]{2}{*}{$\begin{array}{l}\text { INFORMATION } \\
\text { SOURCE }\end{array}$} \\
\hline & & Country & $\begin{array}{c}\text { Protected Area } \\
\text { Age }\end{array}$ & $\operatorname{Area}\left(\mathbf{k m}^{2}\right)$ & $\begin{array}{l}\text { Existence of } \\
\text { Buffer Zones }\end{array}$ & $\begin{array}{l}\text { IUCN P.A } \\
\text { Category }\end{array}$ & $\begin{array}{l}2009 \text { GDP PPP per } \\
\text { capta (Intl } \\
\text { dollars) }\end{array}$ & \begin{tabular}{|} 
Population Density \\
in Vicinity of PA
\end{tabular} & $\begin{array}{c}\text { Local community } \\
\text { participation-decision } \\
\text { making }\end{array}$ & & & \\
\hline Masoala National Park & Moderate & Madagascar & 14 & 2,204 & yes & II & 944.95 & 37.03 & Partially Included & $\begin{array}{l}\text { Some illegal activity } \\
\text { detected: poaching, } \\
\text { fuelwood, logging \& } \\
\text { NTFP* }\end{array}$ & \begin{tabular}{|c|} 
Community is consulted \\
through some meetings, \\
but does not influence PA \\
management
\end{tabular} & $\begin{array}{l}\text { (Ormsby \& Kaplin, } \\
\text { 2005) }\end{array}$ \\
\hline Mantadia National Park & Low & Madagascar & 22 & 154 & yes & II & 944.95 & 28.04 & Excluded & $\begin{array}{l}\text { Frequent illegal activity } \\
\text { detected: Agriculture, } \\
\text { timber, fuelwood \& } \\
\text { NTFP* }\end{array}$ & \begin{tabular}{|c|} 
No participation:there isn't \\
any form of consultation or \\
interaction between \\
community and PA \\
managers.
\end{tabular} & (Shyamsundar, 1996) \\
\hline Kasungu National Park & Low & Malawi & 41 & 2,316 & no & II & 790.15 & 31.94 & Excluded & $\begin{array}{l}\text { Frequent illegal activity } \\
\text { detected: fuelwood, } \\
\text { NTFP*, cattle grazing } \\
\text { and agriculture, } \\
\text { poaching }\end{array}$ & $\begin{array}{c}\text { No participation:there isn't } \\
\text { any form of consultation or } \\
\text { interaction between } \\
\text { community and PA } \\
\text { managers. }\end{array}$ & $\begin{array}{l}\text { (Mkanda \& Munthali, } \\
\text { 1994) }\end{array}$ \\
\hline Batang Ai National Park & High & Malaysia & 20 & 251 & no & II & $13,733.30$ & 6.74 & Included & $\begin{array}{l}\text { no illegal activity } \\
\text { detected }\end{array}$ & $\begin{array}{c}\text { Community plays a major } \\
\text { role on PA management }\end{array}$ & (Horowitz, 1998) \\
\hline $\begin{array}{l}\text { Otoch Ma'ax Yetel Kooh } \\
\text { (OMYK) }\end{array}$ & Moderate & Mexico & 9 & 53 & no & VI & $13,681.32$ & 12.51 & Partially Included & $\begin{array}{l}\text { no illegal activity } \\
\text { mentioned on article but } \\
\text { locals are not completely } \\
\text { satisfied with PA } \\
\text { management. }\end{array}$ & $\begin{array}{c}\text { Community is consulted } \\
\text { through some meetings, } \\
\text { but does not influence PA } \\
\text { management }\end{array}$ & $\begin{array}{l}\text { (Garcia-Frapolli, } \\
\text { Ramos- Fernandes, } \\
\text { Galicia, \& Serrano, } \\
\text { 2009) }\end{array}$ \\
\hline Los Tuxtlas Biosphere Reserve & Low & Mexico & 13 & 1,551 & yes & $\mathrm{VI}$ & $13,681.32$ & 89.63 & Excluded & \begin{tabular}{|l} 
Frequent illegal activity \\
detected: Agriculture, \\
Cattle grazing
\end{tabular} & $\begin{array}{c}\text { No participation:there isn't } \\
\text { any form of consultation or } \\
\text { interaction between } \\
\text { community and PA } \\
\text { managers. }\end{array}$ & $\begin{array}{l}\text { (Durand \& Lazos, } \\
\text { 2008) }\end{array}$ \\
\hline Calakmul Biosphere Reserve & Low & Mexico & 22 & 7,231 & yes & $\mathrm{VI}$ & $13,681.32$ & 10.33 & Excluded & $\begin{array}{l}\text { Frequent illegal activity } \\
\text { detected: Swidden } \\
\text { Agriculture \& Cattle } \\
\text { grazing }\end{array}$ & $\begin{array}{c}\text { No participation:there isn't } \\
\text { any form of consultation or } \\
\text { interaction between } \\
\text { community and PA } \\
\text { managers. }\end{array}$ & $\begin{array}{l}\text { (Garcia-Frapolli, } \\
\text { Ramos- Fernandes, } \\
\text { Galicia, \& Serrano, } \\
\text { 2009) }\end{array}$ \\
\hline Maputo Elephant Reserve & Low & Mozambique & 42 & 900 & no & IV & 954.04 & 12.73 & Excluded & $\begin{array}{l}\text { Frequent illegal activity } \\
\text { detected: Agriculture, } \\
\text { Hunting, Fishing, fuel } \\
\text { wood \& NTFP* }\end{array}$ & $\begin{array}{c}\text { No participation:there isn't } \\
\text { any form of consultation or } \\
\text { interaction between } \\
\text { community and PA } \\
\text { managers. }\end{array}$ & $\begin{array}{c}\text { (De Boer \& Baquete, } \\
\text { 1998) }\end{array}$ \\
\hline $\begin{array}{l}\text { Alaugndaw Kathapa National } \\
\text { Park }\end{array}$ & Moderate & Myanmar & 27 & 1,606 & yes & II & $1,199.74$ & 54.83 & Excluded & $\begin{array}{l}\text { Some illegal activity } \\
\text { detected: Cattle grazing, } \\
\text { timber, fuelwood \& } \\
\text { NTFP* }\end{array}$ & $\begin{array}{c}\text { No participation:there isn't } \\
\text { any form of consultation or } \\
\text { interaction between } \\
\text { community and PA } \\
\text { managers. }\end{array}$ & (Allendorf, et al., 2006) \\
\hline Chatthin Wildlife Sanctuary & Low & Myanmar & 70 & 269 & yes & III & $1,199.74$ & 65.51 & Excluded & $\begin{array}{l}\text { Frequent illegal activity } \\
\text { detected: fuel wood \& } \\
\text { NTFP* }\end{array}$ & \begin{tabular}{|c|c|} 
No participation:there isn't \\
any form of consultation or \\
interaction between \\
community and PA \\
managers.
\end{tabular} & (Allendorf, et al., 2006) \\
\hline Htamanthi wildlife Sanctuary & Moderate & Myanmar & 37 & 2,150 & no & III & $1,199.74$ & 10.58 & Excluded & $\begin{array}{l}\text { Some illegact activity } \\
\text { detected: fuelwood \& } \\
\text { NTFP* }\end{array}$ & $\begin{array}{c}\text { No participation:there isn't } \\
\text { any form of consultation or } \\
\text { interaction between } \\
\text { community and PA } \\
\text { managers. }\end{array}$ & (Allendorf, et al., 2006) \\
\hline
\end{tabular}




\begin{tabular}{|c|c|c|c|c|c|c|c|c|c|c|c|c|}
\hline \multirow[b]{2}{*}{ P.A NAME } & \multirow{2}{*}{\begin{tabular}{|c|} 
OUTCOMES \\
Level of compliance of \\
local community with \\
park's policies
\end{tabular}} & \multicolumn{8}{|c|}{ CHARACTERISTICS } & \multirow[b]{2}{*}{$\begin{array}{l}\text { Notes: Level of } \\
\text { Compliance*** }\end{array}$} & \multirow[b]{2}{*}{$\begin{array}{l}\text { Notes: Level of } \\
\text { Participation**** }\end{array}$} & \multirow[b]{2}{*}{$\begin{array}{l}\text { INFORMATION } \\
\text { SOURCE }\end{array}$} \\
\hline & & Country & $\begin{array}{c}\text { Protected Area } \\
\text { Age }\end{array}$ & Area $\left(\mathbf{k m}^{2}\right)$ & $\begin{array}{l}\text { Existence of } \\
\text { Buffer Zones }\end{array}$ & $\begin{array}{l}\text { IUCN P.A } \\
\text { Category }\end{array}$ & $\begin{array}{c}2009 \text { GDP PPP per } \\
\text { capta (Intl } \\
\text { dollars) }\end{array}$ & $\begin{array}{l}\text { Population Density } \\
\text { in Vicinity of PA }\end{array}$ & $\begin{array}{c}\text { Local community } \\
\text { participation-decision } \\
\text { making }\end{array}$ & & & \\
\hline $\begin{array}{l}\text { Royal Chitwan National Park } \\
\text { (RCNP) }\end{array}$ & Moderate & Nepal & 38 & 932 & yes & II & $1,215.26$ & 322.50 & Partially Included & $\begin{array}{l}\text { Some illegal activity } \\
\text { detected: poaching, } \\
\text { fishing, logging, } \\
\text { fuelwood \& NTFP* }\end{array}$ & $\begin{array}{c}\text { Community is consulted } \\
\text { through some meetings, } \\
\text { but does not influence PA } \\
\text { management }\end{array}$ & $\begin{array}{c}\text { (Straede \& Treue, } \\
\text { 2006) }\end{array}$ \\
\hline Royal Bardia National Park & Moderate & Nepal & 35 & 968 & yes & II & $1,215.26$ & 229.74 & Partially Included & $\begin{array}{l}\text { Some illegal activity } \\
\text { detected: fuelwood, } \\
\text { timber \& NTFP* }\end{array}$ & $\begin{array}{c}\text { Community is consulted } \\
\text { through some meetings, } \\
\text { but does not influence PA } \\
\text { management }\end{array}$ & \begin{tabular}{|c} 
(Baral \& Heinen, \\
2007) and (Allendorf, \\
Smith, \& Anderson, \\
2007)
\end{tabular} \\
\hline Annapurna Conservation Area & High & Nepal & 19 & 7,629 & no & VI & $1,215.26$ & 75.26 & Included & \begin{tabular}{|l} 
no illegal activity \\
detected
\end{tabular} & $\begin{array}{l}\text { Community plays a major } \\
\text { role on PA management }\end{array}$ & $\begin{array}{l}\text { (Bajracharya, Furley, } \\
\text { \& Newton, 2006) }\end{array}$ \\
\hline $\begin{array}{l}\text { Royal Suklaphanta Wildlife } \\
\text { Reserve }\end{array}$ & Moderate & Nepal & 35 & 305 & yes & IV & $1,215.26$ & 308.17 & Partially Included & $\begin{array}{l}\text { Some illegal activity } \\
\text { detected: fuelwood, } \\
\text { timber \& NTFP* }\end{array}$ & $\begin{array}{c}\text { Community is consulted } \\
\text { through some meetings, } \\
\text { but does not influence PA } \\
\text { management }\end{array}$ & $\begin{array}{l}\text { (Baral \& Heinen, } \\
\text { 2007) }\end{array}$ \\
\hline $\begin{array}{l}\text { Makalu Baurun Conservation } \\
\text { Area }\end{array}$ & Moderate & Nepal & 19 & 830 & yes & VI & $1,215.26$ & 49.26 & Partially Included & $\begin{array}{l}\text { Some illegal activity } \\
\text { detected: Cattle grazing, } \\
\text { fuelwood, timber, } \\
\text { poaching \& NTFP* }\end{array}$ & $\begin{array}{c}\text { Community is consulted } \\
\text { through some meetings, } \\
\text { but does not influence PA } \\
\text { management }\end{array}$ & $\begin{array}{l}\text { (Mehta \& Kellert, } \\
\text { 1998) }\end{array}$ \\
\hline Cross River National Park & Low & Nigeria & 20 & 8,000 & yes & II & $2,274.12$ & 60.38 & Excluded & $\begin{array}{l}\text { Frequent illegal activity } \\
\text { detected: fishing, } \\
\text { hunting, fuelwood \& } \\
\text { NTFP }\end{array}$ & $\begin{array}{c}\text { No participation:there isn't } \\
\text { any form of consultation or } \\
\text { interaction between } \\
\text { community and PA } \\
\text { managers. }\end{array}$ & (Ite \& Adams, 2000) \\
\hline $\begin{array}{l}\text { Rajah Sikatuna Protected } \\
\text { Landscape }\end{array}$ & Low & Philippines & 11 & 110 & yes & $\mathrm{v}$ & $3,515.74$ & 243.38 & Excluded & $\begin{array}{l}\text { Frequent illegal activity } \\
\text { detected: Agriculture, } \\
\text { poaching, logging and } \\
\text { NTFP* }\end{array}$ & $\begin{array}{c}\text { No participation:there isn't } \\
\text { any form of consultation or } \\
\text { interaction between } \\
\text { community and PA } \\
\text { managers. }\end{array}$ & $\begin{array}{l}\text { (Lynagh \& Urich, } \\
\text { 2002) }\end{array}$ \\
\hline Kruger National Park & Moderate & South Africa & 85 & 9,150 & no & not known & $10,237.99$ & 21.76 & Partially Included & \begin{tabular}{|l} 
no illegal activity \\
mentioned on article but \\
locals are not completely \\
satisfied with PA \\
management.
\end{tabular} & $\begin{array}{c}\text { Community is consulted } \\
\text { through some meetings, } \\
\text { but does not influence PA } \\
\text { management }\end{array}$ & (Anthony, 2007) \\
\hline $\begin{array}{l}\text { Greater St Lucia Wetland } \\
\text { Nature Reserve }\end{array}$ & Moderate & South Africa & 116 & 2,133 & no & II & $10,237.99$ & 41.70 & Partially Included & $\begin{array}{l}\text { no illegal activity } \\
\text { mentioned on article but } \\
\text { locals are not completely } \\
\text { satisfied with PA } \\
\text { management. }\end{array}$ & $\begin{array}{c}\text { Community is consulted } \\
\text { through some meetings, } \\
\text { but does not influence PA } \\
\text { management }\end{array}$ & (Picard, 2003) \\
\hline $\begin{array}{l}\text { Tsitsikamma National park } \\
\text { (including the terrestrial and } \\
\text { marine park) }\end{array}$ & Low & South Africa & 11 & 298 & no & II & $10,237.99$ & 17.21 & Excluded & $\begin{array}{l}\text { Frequent illegal activity } \\
\text { detected: Fishing \& } \\
\text { Poaching }\end{array}$ & $\begin{array}{c}\text { No participation:there isn't } \\
\text { any form of consultation or } \\
\text { interaction between } \\
\text { community and PA } \\
\text { managers. }\end{array}$ & $\begin{array}{l}\text { (Watts \& Faasen, } \\
\text { 2009) }\end{array}$ \\
\hline $\begin{array}{l}\begin{array}{l}\text { Wu-Wei-Kang Wildlife Refuge } \\
\text { (WWK) }\end{array} \\
\text { (WW }\end{array}$ & High & Taiwan & 18 & 1 & no & not known & $31,769.78$ & 180.10 & Included & $\begin{array}{l}\text { no illegal activity } \\
\text { detected }\end{array}$ & $\begin{array}{c}\text { Community plays a major } \\
\text { role on PA management }\end{array}$ & $\begin{array}{c}\text { (Lu, Chou, \& Yuan, } \\
\text { 2005) }\end{array}$ \\
\hline Serengeti National Park & Moderate & Tanzania & 60 & 14,763 & no & II & $1,340.91$ & 50.75 & Partially Included & $\begin{array}{l}\text { Some illegal activity } \\
\text { detected: Cattle grazing }\end{array}$ & $\begin{array}{c}\text { Community is consulted } \\
\text { through some meetings, } \\
\text { but does not influence PA } \\
\text { management }\end{array}$ & $\begin{array}{c}\text { (Kaltenborn, } \\
\text { Nyahongo, Kidegesho, } \\
\& \text { Haaland, 2008) }\end{array}$ \\
\hline
\end{tabular}




\begin{tabular}{|c|c|c|c|c|c|c|c|c|c|c|c|c|}
\hline \multirow[b]{2}{*}{ P.A NAME } & \multirow{2}{*}{\begin{tabular}{|c|} 
OUTCOMES \\
\\
Level of compliance of \\
local community with \\
park's policies \\
\end{tabular}} & \multicolumn{8}{|c|}{ CHARACTERISTICS } & \multirow[b]{2}{*}{$\begin{array}{l}\text { Notes: Level of } \\
\text { Compliance*** }\end{array}$} & \multirow[b]{2}{*}{$\begin{array}{l}\text { Notes: Level of } \\
\text { Participation**** }\end{array}$} & \multirow[b]{2}{*}{$\begin{array}{l}\text { INFORMATION } \\
\text { SOURCE }\end{array}$} \\
\hline & & Country & $\begin{array}{c}\text { Protected Area } \\
\text { Age }\end{array}$ & $\operatorname{Area}\left(\mathbf{k m}^{2}\right)$ & $\begin{array}{l}\text { Existence of } \\
\text { Buffer Zones }\end{array}$ & $\begin{array}{l}\text { IUCN P.A } \\
\text { Category }\end{array}$ & $\begin{array}{l}2009 \text { GDP PPP per } \\
\text { capta (Intl } \\
\text { dollars) }\end{array}$ & $\begin{array}{l}\text { Population Density } \\
\text { in Vicinity of PA }\end{array}$ & $\begin{array}{c}\text { Local community } \\
\text { participation-decision } \\
\text { making }\end{array}$ & & & \\
\hline Selous Game Reserve & Moderate & Tanzania & 106 & 44,000 & yes & IV & $1,340.91$ & 15.90 & Partially Included & \begin{tabular}{|l|} 
no illegal activity \\
mentioned on article but \\
locals are not completely \\
satisfied with PA \\
management.
\end{tabular} & $\begin{array}{c}\text { Community is consulted } \\
\text { through some meetings, } \\
\text { but does not influence PA } \\
\text { management }\end{array}$ & $\begin{array}{c}\text { (Gillingham \& Lee, } \\
\text { 2003) }\end{array}$ \\
\hline Katavi National Park & Moderate & Tanzania & 37 & 4,471 & no & II & $1,340.91$ & 12.49 & Partially Included & $\begin{array}{l}\text { Some illegal activity } \\
\text { detected: Logging \& } \\
\text { Fuelwood }\end{array}$ & \begin{tabular}{|c|}
$\begin{array}{c}\text { Community is consulted } \\
\text { through some meetings, } \\
\text { but does not influence PA } \\
\text { management }\end{array}$ \\
\end{tabular} & (Holmes, 2003) \\
\hline Khao Yai National Park & Moderate & Thailand & 49 & 2,185 & no & II & $8,488.69$ & 87.12 & Excluded & $\begin{array}{l}\text { Some illegal activity } \\
\text { detected: Agriculture, } \\
\text { Fuelwood, logging } \\
\text { \&NTFP* }\end{array}$ & $\begin{array}{c}\text { No participation:there isn't } \\
\text { any form of consultation or } \\
\text { interaction between } \\
\text { community and PA } \\
\text { managers. }\end{array}$ & $\begin{array}{c}\text { (Albers \& Grinspoon, } \\
\text { 1997) } \\
\end{array}$ \\
\hline Kibale National Park & Low & Uganda & 20 & 766 & no & II & $1,210.42$ & 197.89 & Excluded & \begin{tabular}{|l|} 
no illegal activity \\
mentioned but locals are \\
extremely dissatisfied \\
with park's managemnet.
\end{tabular} & $\begin{array}{c}\text { No participation:there isn't } \\
\text { any form of consultation or } \\
\text { interaction between } \\
\text { community and PA } \\
\text { managers. }\end{array}$ & $\begin{array}{l}\text { (Lepp \& Holland, } \\
\text { 2006) }\end{array}$ \\
\hline \begin{tabular}{|l|} 
Kibale Association for Rural and \\
Economic Development \\
(KAFRED)
\end{tabular} & High & Uganda & 17 & not known & no & not known & $1,210.42$ & 281.00 & Included & \begin{tabular}{|l} 
no illegal activity \\
detected
\end{tabular} & $\begin{array}{l}\text { Community plays a major } \\
\text { role on PA management }\end{array}$ & $\begin{array}{l}\text { (Lepp \& Holland, } \\
\text { 2006) }\end{array}$ \\
\hline Lake Mburo National Park & Low & Uganda & 29 & 370 & no & II & $1,210.42$ & 81.34 & Partially Included & \begin{tabular}{|l|} 
Frequent illegal activity \\
detected: Agriculture, \\
Cattle grazing \& \\
Poaching
\end{tabular} & $\begin{array}{c}\text { Community is consulted } \\
\text { through some meetings, } \\
\text { but does not influence PA } \\
\text { management }\end{array}$ & $\begin{array}{l}\text { (Infield \& Namara, } \\
\text { 2001) }\end{array}$ \\
\hline $\begin{array}{l}\text { Bwindi Impenetrable National } \\
\text { Park }\end{array}$ & High & Uganda & 20 & 327 & no & II & $1,210.42$ & 212.86 & Included & \begin{tabular}{|l} 
no illegal activity \\
detected
\end{tabular} & $\begin{array}{l}\text { Community plays a major } \\
\text { role on PA management }\end{array}$ & $\begin{array}{l}\text { (Hamilton, } \\
\text { Cunningham, } \\
\text { Byarugaba, \& Kayanja, } \\
\text { 2000) }\end{array}$ \\
\hline Mgahinga Gorila National Park & High & Uganda & 81 & 38 & no & II & $1,210.42$ & 484.67 & Partially Included & \begin{tabular}{|l} 
no illegal activity \\
detected
\end{tabular} & $\begin{array}{c}\text { Community is consulted } \\
\text { through some meetings, } \\
\text { but does not influence PA } \\
\text { management }\end{array}$ & $\begin{array}{l}\text { (Adams \& Infield, } \\
\text { 2001) }\end{array}$ \\
\hline Phong Dien Nature Reserve & Low & Vietnam & 10 & 414 & no & not known & $2,941.67$ & 45.65 & Excluded & \begin{tabular}{|l|} 
Frequent illegal activity \\
detected: NTFP*, \\
Timber \& Poaching
\end{tabular} & $\begin{array}{c}\text { No participation:there isn't } \\
\text { any form of consultation or } \\
\text { interaction between } \\
\text { community and PA } \\
\text { managers. }\end{array}$ & $\begin{array}{l}\text { (Boissiere, Sheil, } \\
\text { Basuki, Wan, \& Le, } \\
\text { 2009) }\end{array}$ \\
\hline Gonarezhou National Park & Low & Zimbabwe & 36 & 5,053 & no & II & 394.30 & 16.91 & Excluded & \begin{tabular}{|l|} 
Frequent illegal activity \\
detected: Agriculture, \\
poaching \& Cattle \\
grazing
\end{tabular} & $\begin{array}{c}\text { No participation:there isn't } \\
\text { any form of consultation or } \\
\text { interaction between } \\
\text { community and PA } \\
\text { managers. }\end{array}$ & $\begin{array}{l}\text { (Mombeshora \& Le } \\
\text { Bel, 2009) }\end{array}$ \\
\hline
\end{tabular}

NTFP*: Non Timber Forest Product

${ }^{* *}$ Frequency and type of illegal activity detected on PA case studies

*** Level of community participation specified on PA case studies 


\section{LITERATURE CITED}

Abakerli, S. (2001). A critique of development and conservation policies in environmentally sensitive regions in Brazil. Geoforum 32:551-565.

Abbot, J., Thomas, D., Gardner, A., Neba, S., \& Khen, M. (2001). Understanding the Links Between Conservation and Development in the Bamenda Highlands, Cameroon. World Development 29(7):1115-1136.

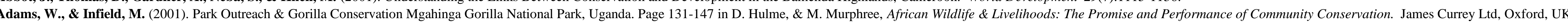
Akama, J., Lant, C., \& Burnett, G. (1995). Conflicting Attitudes Towards State Wildlife Conservation Programs in Kenya'. Society and Natural Resources 8:133-144.

Albers, H., \& Grinspoon, E. (1997). 'A comparison of the enforcement of access restriction between Xishuangbanna Nature Reserve (China) and Khao Yai National Park (Thailand). Environmental Conservation 24(4):351-362.

Allendorf, T, Smith, J, \& Anderson, D. H. (2007). Residents' perceptions of Royal Bardia National Park, Nepal. Landscape and Urban Planning 82:33-40.

Allendorf, T., Swe, K., OO, T., Htut, Y., Aung, M., Allendorf, K., et al. (2006). Community attitudes toward three protected areas in Upper Myanmar (Burma). Environmental Conservation 33(4):344-352.

Anthony, B. (2007). The dual nature of parks: attitudes of neighbouring communities towards Kruger National Park, South Africa. Environmental Conservation 34(3):236-245.

Arjunan, B.

Bajracharya, S., Furley, P., \& Newton, A. (2006). Impacts of community-based conservation on local communities in the Annapurna Conservation Area, Nepal. Biodiversity and Conservation 15:2765-2786.

Baral, N., \& Heinen, J. (2007). Decentralization and people's participation in conservation: a comparative study from the Western Terai of Nepal. International Journal of Sustainable Development and World Ecology 14:520-531.

Bauer, H. (2003). Local perceptions of Waza National Park, northern Cameroon. Environmental Conservation 30(2):175-181.

Boissiere, M., Sheil, D., Basuki, I., Wan, M., \& Le, H. (2009). Can engaging local people's interests reduce forest degradation in Central Vietnam?. Biodiversity Conservation 18:2743-2757.

De Boer, W., \& Baquete, D. S. (1998). Natural resource use, crop damage and attitude of rural people in the vicinity of the Maputo Elephante Reserve, Mozambique. Environmental Conservation 25(3):208- 218.

Durand, L., \& Lazos, E. (2008). The Local perception of Tropical Deforestation and its Relation to Conservation Policies in Los Tuxtlas Biosphere Reserve, Mexico. Human Ecology 36:383-394.

Fiallo, E., \& Jacobson, S. (1995). Local Communities and Protected Areas: Attitude of Rural Residents Towards Conservation and Machalilla National Park, Ecuador. Environmental Conservation 22(3):241-249.

Fu, B., Wang, K., Lu, Y., Liu, S., Ma, K., Chen, L., et al. (2004). Entangling the Complexity of Protected Area Management: The Case of Wolong Biosphere Reserve, Southwestern China. Environmental Management 33(6):788-798.

Garcia-Frapolli, E., Ramos- Fernandes, G., Galicia, E., \& Serrano, A. (2009). The complex reality of biodiversity conservation through Natural Protected area policy: Three cases Studies from yucatan Pneninsula, Mexico. Land Use Policy 26:715-722.

Gillingham, S., \& Lee, P. (2003). People and protected areas: a study of local people perceptions of wildlife crop-damage conflict in an area bordering the Selous Game Reserve. Oryx 37(3):316-325.

Grainger, J. (2003). People are living in the park. Linking biodiversity consereavtion to community development in the Middle East region: a case study from the Saint Katherine Protectorate, Sourthern Sinai. Journal of Arid Environment 54:29-38.

Hamilton, A., Cunningham, A., Byarugaba, D., \& Kayanja. (2000). Conservation in a Region of Political Instability: Bwindi Impenetrable Forest, Uganda. Conservation Biology 14(6):1722-1725.

Holmes, C. M. (2003). The influence of protected area outreach on conservation attitude and resource use patterns: a case study from western Tanzania. Oryx 37(3):305-315.

Horowitz, L. S. (1998). Integrating Indigienous Resource management with Wildlife Conservation: A Case Study of Batang Ai National Park, Sarawak, Malaysia. Human Ecology 26(3):371-403.

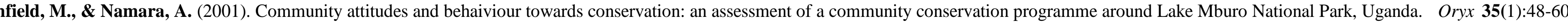

Ite, U., \& Adams, W. (2000).Expectation, Impacts, and attitude: Conservation and Development in Cross River National Park, Nigeria. Journal of International Development 12:325-342.

Jim, C., \& Xu, S. (2002). Stifled Stakeholders and Subdue Participation: Interpreting Local Responses Toward Shimentai Nature Reserve in South China. Environmental Management 30(3):327-34 .

Kaltenborn, B., Nyahongo, J., Kidegesho, J., \& Haaland, H. (2008). Serengeti National Park and its neighbours- Do they interact? Journal for Nature Conservation 16:96-108.

Lepp, A., \& Holland, S. (2006). A Comparison of Attitudes Towards State-Led Conservation and Community-Based Conservation in the Village of Bigodi, Uganda. Society and Natural Resources 19:609-623.

Lu, D., Chou, Y., \& Yuan, H. (2005). Paradigm shift in the instutional arrangement of protected areas management in Taiwan: a case study of Wu-Wei-Kang Waterfowl Wildlife Refuge in Ilan. Taiwan. Environmental Science \& Policy 8:418-430.

Lynagh, F., \& Urich, P. (2002). A Critical Review of Buffer Zone Theory and Practice: A philippine Case Study. Society and Natural Resources 15:129-145.

Maikhuri, R., S., N., \& Rao, K. S. (2001). Conservation policy-people conflicts: a case study from Nanda Devi Biosphere Reserve (a World Heriatge Site), India. Forest Policy and Economics 2:355-365.

Mayaka, T. (2002). Wild life Co-Management in the Benoue National Park-Complex, Cameroon: A Bumby Road to Instutional Development. World Development 30(11):2001-2016.

Mbile, P., Vat, N., Mebre of Korup National Park Cameroon. Journal of Environmental Management 76:1-13.

Mehta, J., \& Kellert, S. (1998). Local attitudes toward community-based xonservation and programmes in Nepal: a case study in the Makalu-Barun Conservation Area. Environmental Conservation 25(4):320-333.

Mkanda, F., \& Munthali, S. (1994). Public attitudes and needs around Kasungu National Park, Malawi. Biodiversity and Conservation 3:29-44

Mombeshora, S., \& Le Bel, S. (2009). Parks-people conflicts: the case of Gonarezhou National Park and the Chitsa community in south-east Zimbabwe. Biodiversity Conservation 18:2601-2623.

Mukherjee, A., \& Borad, C. (2004). Integrated approach towards conservation of Gir National Park: The last refuge of Asiatic Lions, India. Biodiversity and Conservation 13:2165-2182.

Nagendra, H., Pareeth, S., \& Ghate, R. (2006). People within parks-forest villages, Land-cover change and landscape fragmentation in the Tadoba Andhari Tiger Reserve, India. Applied Geography 26:96-112.

Ogra, M. (2009). Attitudes Toward Resolution of Human-Wildlife Conflict Among Forest-Dependent Agriculturalists Near Rajaji National Park. India. Human Ecology 37:161-177.

Ormsby, A., \& Kaplin, B. (2005). A framework for understanding community resident perceptions of Masoala National Park, Madagascar. Environmental Conservation 32(2):154-164.

Picard, C. (2003). Post-apartheid perceptions of the Greater St Lucia Wetland Park, South Africa. Environmental Conservation 30(2): 182-191.

Sekhar, N. (2003). Local people's attitude towards conservation and wildlife tourism around Sariska Tiger Reserve, India. Journal of Environmental Masag
Shyamsundar, P. (1996). Constraints on socio-buffering around the Mantadia National Park in Madagascar. Environmental Conservation 23(1):67-73.

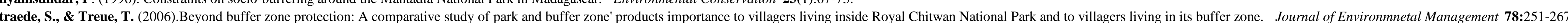

Usongo, L., \& Nkanje, T. (2004). Participatory approaches towards forest conservation: The case of Lobeke National Park, South east Camerron. International Journal of Sustainable Development and World Ecology 11:119-127.

Wang, S., Lassoie, J., \& Curtis, P. (2006). Farmer attitude towards conservation in Jigme Singye Wangchuck National Park, Bhutan. Environmental Conservation 33(2):148-156.

Watts, S., \& Faasen, H. (2009). Community-Based Conflict Resolution Strategies for Sustainable Management of the Tsitsikamma National Park, South Africa. South African Geographical Journal 91(1):25-37.

Yonariza, \& Webb, E. (2007). Rural household participation in illegal timber felling in a protected area of West Sumatra, Indonesia. Environmental Conservation 34(1):73-82.

Zimmerman, B., Peres, C., Malcolm, J., \& Turner, T. (2001).Conservation and development alliances with Kayapo of south-eastern Amazonia, a tropical forest indiginous people. Environmental Conservation 28(1):10-22. 